\title{
Arrangement of Interactive Media Based Teaching of Literature Sciences in Indonesian Language and Literature Faculty of Language and Arts of Medan State University
}

\author{
Rosmawaty \\ Lecturer on State University of Medan, North Sumatera Indonesia
}

\begin{abstract}
The objectives of this study are: (1) To produce interactive media-based literature introductory teaching materials, easy and interesting to use, (2) Knowing student assessment of interactive media-based literature introduction instructional materials. This type of research is development research that uses the Brog and Gel product development model combined with the Dick and Carey learning development model. This learning product development model is a model that is programmed in a systematic order and meets the characteristics of students in learning. The last trial subjects were from two Indonesian language subject matter experts, two instructional media design experts, three students for individual tests, 9 students for small group tests and field tests. Data about the quality of these development products was collected by a questionnaire. Data collected were analyzed using qualitative descriptive techniques. The results of the preparation research show: (1) expert test of introductory material in literary science is included in the excellent category $(92.28 \%)$, (2) the learning media design expert test in the category of very good $(92.36 \%$ (3) individual test are in very good quality $(96.36 \%(4)$ small group tests are in very good quality $(95.73 \%)$ and the final assessment of field tests is in very good quality $(97.52 \%)$, from the results of the overall assessment of introductory teaching materials Interactive media-based literary sciences included in the category of very good with an average (94.84\%). Thus, it was concluded that the introduction of instructional materials based on interactive media-based literature at FBS Medan State University is appropriate to use.
\end{abstract}

Keywords: teaching materials, literature, media, interactive

DOI: $10.7176 / \mathrm{JEP} / 11-5-08$

Publication date: February $29^{\text {th }} 2020$

\section{Introduction}

Literature as a science is still often debated. Objections that have been submitted to general literature because there is no individual attention, for literary works as a unique work of art. "He said, literary science only wanted to find schemes for how to tell a convention in poetry and communication modules without regard to the story or the only poem, which could not be replaced by another story or poem. Not confusing the problem, because every literary scientist tries to formulate common understandings. He wants to know the characteristics that are characteristic of all literary works or a group of literary works. The rules and conventions specifically apply when we encounter literary texts (Luxemburg, et al., 1989: 2 - 3).

The rejection of literature as a science is also expressed by Wellek and Austin. They argue that literature is a creative activity, a work of art. While the study/science of literature is a branch of science. However, a number of theorists flatly rejected that the study of literature is a science (Wellek and Austin, 1989: 3).

Literature as a field of science is different from other sciences. The difference is in attention, in appreciation, not in cognition. "The object of literary science is human life that has been abstracted in literary works" (Budi Darma, 1990: 338). Therefore, in the science of literature, literature as the main object of study has unique characteristics that are different from the objects of other scientific studies. Besides direct or indirect literary science always puts forward inquiry, problems, covert hypotheses and answers to inquiry, problems and proof of covert hypotheses (Budi Darma, 1990a: 342). The stages in the science of literature are not hierarchically tiered as in science in general (from knowledge, understanding, application, analysis, synthesis, and finally evaluation), but rather are broad.

Learning media is very important in the learning process. Media is a tool whose function is to transfer knowledge to students. This is in accordance with the statement Sadiman (2014: 7) which states that, "the media is everything that is used to channel a message to the recipient, whose aim is to be able to stimulate the thoughts, feelings, concerns, and interests and concerns of students so that the learning process occurs "As the development of information and communication technology in this modern era, teachers are required to be able to create or develop teaching materials by designing interactive media.

Interactive media in a learning environment can support students to become critical thinkers quickly. The fact that there is a lack of learning design is what causes the learning environment to be low. 


\section{Research Model}

The preparation of this interactive media-based literary introductory teaching material will be held at the FBS Department of Indonesian Language UNIMED Medan. The validator is asked to write the appropriate score by putting a check mark () in the appropriate row and column. The validator is also asked to provide general conclusions about the lesson plan, student activity sheets, and test results of learning by categories, namely: not good, not good enough, good enough, good, very good, can not be used and still requires consultation, can be used with many revisions, can be used with few revisions, and can be used without revision. The components, functions and uses of each validation sheet will be described in detail, presented as follows:

\subsection{Teaching Material Validation Sheet}

Data collected with this validation sheet is data about the validity of the material. The media validation sheet consists of the assessment instructions, the rating scale, the assessment table contains aspects that are assessed, indicators of each aspect, suggestions and comments from the validator. The criteria for stating that the validity of interactive media-based teaching materials is based on valid or does not consist of 5 (five) rating scales, namely, invalid (value 1); less valid (value 2); quite valid (value 3); valid (value 4) and very valid (value 5).

\subsection{Semester Learning Plan Validation Sheet}

The data collected with this validation sheet is data about the validity of the RPS. The validation sheet of the learning implementation plan consists of three components, namely the instructions, aspects to be assessed, and the results of the assessment. The validity assessment of the learning implementation plan developed was reviewed from 3 aspects, namely (1) the format of the RPS (2) the content of the RPS (3) the use of language. The criteria for stating that the learning implementation plan developed is valid consists of 5 (five) rating scales namely, invalid (value 1); less valid (value 2); quite valid (value 3); valid (value 4); and very valid (value 5).

\subsection{Validation Sheet Student Activity Sheet}

Data collected about the validity of student activity sheets. The validation sheet consists of three student activity sheets, namely instructions, aspects to be assessed, and assessment results. Validity Rating

The student activity sheet that was developed was reviewed from 3 aspects, namely (1) the worksheet format, (2) the appropriateness of the contents (3) the language. The criteria for stating that the student activity sheet developed is valid consists of 5 (five) rating scales namely, invalid (value 1), less valid (value 2), quite valid (value 3 ), valid (value 4 ), very valid (value 5 ).

\subsection{Expert and Practitioner Evaluation Sheet on Practicality}

This assessment sheet is used to measure the practicality of learning tools that have been created based on the mastery of theory and the experience of experts and practitioners. The technique used to obtain this data is to provide learning tools and assessment sheets to experts and practitioners.

\subsection{Data Analysis}

The data analysis technique used in this research is descriptive analysis.

\subsection{Data Analysis of Learning Device Validation Results}

The data on the validity assessment of the learning tools based on problems from several experts who are competent in the field of literary learning tools compilation, and practitioners determined the average value of the indicators and the value of aspects for each expert and practitioner.

\subsection{Practical Analysis of Learning Devices}

The way to analyze the practicality of a learning device is to provide a learning tool for the validator to be validated. According to Sugiyono (201: 92), learning tools are said to be practical if the validator states that the developed learning tools can be applied and used in the field with little or no revision

\subsection{Data Analysis on Practicality of Teaching Materials}

How to analyze the practicality of instructional materials compiled by providing learning materials to the validator to be validated. Teaching Material is said to be practical if the validator states that the developed teaching material can be applied and used in the field with little or no revision. The results of the observation sheet during the learning process with interactive media-based teaching materials can show a positive increase in student activity and the teacher's ability to manage learning. Determine the success or failure of student achievement on attitude competency can be done by comparing the acquisition value with those that have been set for literary courses.. 


\section{Research Results}

\subsection{Analysis of Student Activity Data}

Data observations of student activities during learning activities were analyzed based on percentages. The percentage of student activity that is the frequency of each aspect of observation divided by the total frequency of all aspects of observation multiplied by $100 \%$ or, The percentage of student activity is Determination of the effectiveness criteria for student activity based on achieving the ideal time specified in the preparation of learning plans based on problems, see table 1.

Table 1. Effectiveness of Student Activities

\begin{tabular}{|l|c|c|}
\hline \multicolumn{1}{|c|}{ Category Student Activity } & \multicolumn{2}{|c|}{ Effective Percentage (P) } \\
\cline { 2 - 3 } & Ideal Time & Tolerance \\
\hline - Paying attention / listening to the explanation of the lecturer / friend & $14 \%$ & $12 \%-22 \%$ \\
\hline $\begin{array}{l}\text { - Reading / understanding the problem of teaching material introduction to } \\
\text { literary science by applying interactive media }\end{array}$ & $11 \%$ & $6 \%-16 \%$ \\
\hline $\begin{array}{l}\text { - Solve problems / find ways that can be applied from an introduction to } \\
\text { literature }\end{array}$ & $28 \%$ & $23 \%-33 \%$ \\
\hline - Discuss / ask friends or lecturers & $33 \%$ & $28 \%-38 \%$ \\
\hline - Draw conclusions for a procedure or scenario & $11 \%$ & $6 \%-16 \%$ \\
\hline - Student behavior that is not relevant to KBM & $0 \%$ & $0 \%-5 \%$ \\
\hline
\end{tabular}

\subsection{Discussion of Research Results}

\subsubsection{Discussion of Product Feasibility Test Results}

Interactive media-based learning development products on introductory learning of literary science are introductory material on literary science that has been developed by paying attention to aspects of learning and the media as a principle of learning message design. The product compilation research that was conducted was directed to produce a product in the form of interactive media-based literature on instructional literature on introductory literature for FBS UNIMED students used to improve the learning process and the competence of students. Therefore, in the process this research was conducted with a preliminary study beginning. Then design learning media, validate products, make revisions and refinements based on validation data analysis from material experts, instructional media design experts, followed by individual trials, small group trials, and field trials to produce appropriate learning media according with the characteristics of the field of study and students as users.

Aspects that are revised and refined based on data analysis and trials and input from material experts, instructional media design experts and students as users of interactive media-based literary teaching materials, aim to explore some aspects that are fair in the process of developing a product. Learning media variables have a very good average value. The learning media variables assessed include content worthiness, presentation, language, programming and graphics which will be tested by each expert.

The following results summarize the average percentage of the results of the assessment of interactive media-based literature introductory teaching materials on the introductory material of FBS UNIMED literature by material experts, instructional media, learning designs, individual trials, small group trials, and field trials can be seen in the following table 2 :

Table 2. Summary of Assessment Results of the Interactive Media Product Feasibility Test

\begin{tabular}{|l|l|c|l|}
\hline No & \multicolumn{1}{|c|}{ Respondents } & Average Percentage & Criteria \\
\hline 1 & Expert Learning Material & $92.29 \%$ & very good \\
\hline 2 & Learning Media Experts & $92.36 \%$ & very good \\
\hline 3 & Learning Design Experts & $91.51 \%$ & very good \\
\hline 4 & Students on Individual Trial & $96,36 \%$ & very good \\
\hline 5 & Students in the Small Group Trial & $95,75 \%$ & very good \\
\hline 6 & Students in Field Trial & $97.52 \%$ & very good \\
\hline & Average & $\mathbf{9 4 . 2 9 \%}$ & very good \\
\hline
\end{tabular}

The results of the feasibility test assessment conducted by material, media and design experts in the table above, can be seen the average value of $94.29 \%$ with a very good category. Thus it can be concluded that interactive media-based learning in the introduction to FBS UNIMED literature is feasible to be used in the learning process.

The benefits obtained from the use of interactive media-based learning are concepts that are presented easily learned, understood and systematic. Interactive media-based learning gives students the opportunity to learn in accordance with their respective speeds, learn faster and not cause boredom because it is equipped with images and animations as well as a variety of practice questions. Interactive multimedia-based learning can also be used as an alternative learning media that can be done both classically and individually. 


\subsubsection{Discussion of the Excellence Features of Interactive Media-Based Literature Teaching Material in the Introduction to Literature}

Interactive media is a learning media that has many advantages. One of the advantages of interactive media is that it can increase student motivation. Student learning motivation that increases well can improve learning outcomes as well. This can be seen from the results of student learning when using newspaper and textbook media compared to when using interactive media which have very different average values.

The average value of student learning outcomes in understanding the introduction to the science of literature using textbooks and newspapers is $\mathbf{5 7 . 2 8}$ and the average value of student learning outcomes using interactive media is 83.00. From the results of student learning, it can be seen that FBS UNIMED students are more motivated and interested in using interactive media in introductory learning in literary science.

\subsection{Research Limitations}

Limitations in research on developing interactive learning media and testing the effectiveness of this product include.

(1). The trial of interactive multimedia-based learning products is only carried out in limited trials with a sample of 35 FBS UNIMED students. Extensive trials were not carried out so that possible bias factors still influence the results of the study. Therefore the sample in the study must be large in number so that the research results can be generalized.

(2). The unpreparedness of introductory lecturers to engage in interactive media-based learning in the learning process. Lecturers are accustomed to giving learning material using drawing media then giving assignments in a structured manner, then evaluating to determine the assessment of student learning outcomes. The unpreparedness of lecturers to use interactive media-based learning can be overcome by training to improve competency professionally.

(3). The unpreparedness of students to be involved in a learning media that is different from the learning media they normally use. The unpreparedness of students can be overcome by giving learning CDs so that they can be used as tools used for independent learning so as to improve student competency and student learning outcomes.

(4). Limited facilities and infrastructure in making interactive media-based learning. This will hinder researchers in the effort to compile interactive media-based learning in the UNIMED FBS environment.

\section{Conclusion}

Based on the formulation, objectives, results and discussion of research development of instructional materials for introducing interactive media-based literature, it can be concluded as follows.

(1). The results of the validation assessment of material experts, instructional material design instructors on interactive media-based literary science, individual trial responses, small group trials, and field trials on interactive media-based literary teaching materials are developed showing that all aspects of assessment Interactive media-based learning as a whole is included in the category of "Very Good" with a percentage of $94.29 \%$ so it is feasible to use in the learning process.

(2). Interactive media-based learning has an effectiveness of $83 \%$ higher than the effectiveness of print media such as books and newspapers by $57.28 \%$. The feature of introductory teaching materials on interactive media-based literary science is an effective learning media used in learning, in addition to the effective use of instructional materials based on interactive media-based literature has many advantages. One of the advantages of interactive media is that it can increase student motivation. Student learning motivation that increases well can improve learning outcomes as well. This can be seen from the results of student learning when using textbook media compared to when using interactive media which have very different average values.

(3). The average value of student learning outcomes in introductory literature using 57.28 textbooks and the average value of student learning outcomes using interactive media-based literature introductory teaching materials is 83.00. From the results of student learning, it can be seen that FBS UNIMED students are more motivated and interested in using interactive media-based literary instructional materials in the introduction to literary science. By using media, introductory material for literary science can be presented more interestingly than just using media such as text, images, or Microsoft PowerPoint.

(4). In the introductory teaching materials on interactive media-based literature on introductory literature, not only videos can be displayed, but learning about introductory literature and evaluation of learning accompanied by audio can be presented simultaneously. So students can learn to relax classically or independently. The advantages of interactive media features is what makes the reason researchers make learning to write news texts using interactive multimedia. 


\section{References}

Darma, Budi, 1990. "Perihal Studi Sastra". Dalam Basis

Darma, Budi, 1990a. Olenka. Jakarta : Balai Pustaka.

Luxemburg, Jan Van. Dkk., 1989. Pengantar Ilmu Sastra. Terjemahan Dick Hartoko. Jakarta: PT Gramedia.

Sugiyono, 2013. Metode Penelitian Pendidikan Pendekatan Kuantitatif, Kualitatif, dan R\&D. Bandung: Alfabeta.

Sadiman, 2014. Media Pendidikan: Pengertian, Pengembangan, dan Pemanfaatannya. Jakarta : PT. Raja Grafindo Persada.

Wellek, Rene dan Austin , 1989. Teori Kesusastraan. Jakarta: Gramedia. 